\title{
Policy of foreign direct investment liberalisation in India: implications for retail sector
}

\author{
Utsav Masharu ${ }^{1} \cdot$ Muhammad Ali Nasir $^{1}$ (D)
}

Received: 2 May 2017 / Accepted: 2 July 2018 / Published online: 6 July 2018

(C) The Author(s) 2018

\begin{abstract}
This study has analysed the impact of liberalisation of Indian economy and FDI policy on the retail sector since its implementation in the 1990s. It also further analyses sub-categories by investigating its impact on the unorganised retail sector and the flow of FDI in single-brand retail and multi-brand retail sectors. A comprehensive and critical review of the existing evidence on the subject was carried out, and descriptive statistical analysis of data from 1991 to 2013 was performed which leads to conclude that the policy of FDI liberalisation has proved to provide diversification and sustainable development to the Indian economy and specifically retail sector which is considered to be one of the significant pillars of economy. Furthermore, for continuous growth of the economy, it seems vital to encourage more investment in other sectors by liberalising the restrictive policies.
\end{abstract}

Keywords FDI · Trade liberalisation · Transition economies · Retail sector · Organised and unorganised retail $\cdot$ Single-brand retail and multi-brand retail

JEL Classification F10 $\cdot$ F13 $\cdot$ F21 $\cdot$ L81 $\cdot$ L88

\section{Introduction and background}

In the contemporary markets economies, retailing is a significant link between producers and consumers. In order to build a strong relationship between the two, retailers not only offer a wide range of products, but also provide complementary services to the consumers, both of which together provides satisfactory and convenience experience of shopping for consumers. The retailing sector is considered as one of the significant pillars of the Indian economy, which is expanding at remarkable pace. India could be rightly referred as the nation of shopkeepers

Muhammad Ali Nasir

m.a.nasir@leedsbeckett.ac.uk

1 School of Accounting, Finance and Economics, Faculty of Business and Law, Leeds Beckett University, The Rose Bowl, Portland Crescent, Leeds LS1 3HB, UK 
since a long time, as more than 15 million retail outlets have been established in the retail sector (Mukherjee and Patel 2005).

Since the liberalisation of FDI policies started in the early 1990s, the Indian economy has welcomed many multi-national corporations (MNCs) to invest and was ascertained to receive the humongous amount of foreign investment in the future. The retail sector of India went through a gigantic transformation in the last two decades. In 2013, the market value of the Indian retail sector was the US \$500 billion and is considered to be one of the top five retail markets with a population of 40 million engaged in it. The retail sector is expanding at a rapid pace, with a gradual shift in formats towards organised retailing. It is anticipated to reach at USD 900 billion by the end of 2017, representing compound annual growth rate (CAGR) of more than 12\% (Ernst and Young Report 2013). Retail sector provides employment of $8 \%$ to the total workforce and contributes over $10 \%$ of GDP to the economy (IBEF Report 2014). Retail sector is broadly divided into two major sectors: organised sector and unorganised sector. Currently, India's retail sector is at a nascent stage where $92 \%$ of the retail sector is unorganised retail such as vendors, street markets, hole-in-wall shops, mom-n-pop stores and roadside hawkers. Unorganised retailing is categorised based on lack of knowledge about inventory control, supply chain management, government policies, taxation rules and standardisation of product. On the other hand, only $8 \%$ of the retail sector is organised (in USA 85\%) which includes licensed retailers like hypermarkets, supermarkets, retail chains and mega-stores.

Before the initiation of liberalisation of FDI policies, organised sector growth was slow due to significant restriction on consumer goods and consumerism. Slow growth was due to high taxation rate and rigid licensing policies on imported goods discouraging foreign investors towards consumer goods industry. The benefit towards economies of scale was affected due to lack of wide variety of products. Further, the development of scale was also limited due to restriction on interstate movement of goods and stock. Overall the growth of retail sector was constrained due to low income of the consumers followed by high taxation and poor government support. After the liberalisation and economic reforms in 1991, the sector started evolving; imposed restrictions were relaxed leading to the development of the economy. Thus, consumer good industry exhibited significant growth in the limited span of time. Many multi-national companies (MNCs) such as Sony, Samsung, and Kellogg's entered in the market due to the removal of entry barriers (Mukherjee and Patel 2005). The government of India had been focusing progressively on changing economic reforms and liberalisation of the retail sector in order to attract foreign investors. Therefore, it led to the initiation of competitiveness among domestic enterprises through access to global formats, retail innovation, availability of goods to the consumers and increasing technology and management practices. The liberalisation of the retail sector to universal competition is likely to motivate retail rush and to transform retailing landscape and country's ailing infrastructure in India. Organised retail trade is traditionally divided into two trades: single-brand retail trade (SBRT) and multi-brand retail trade (MBRT). Both trades enable growth in the 


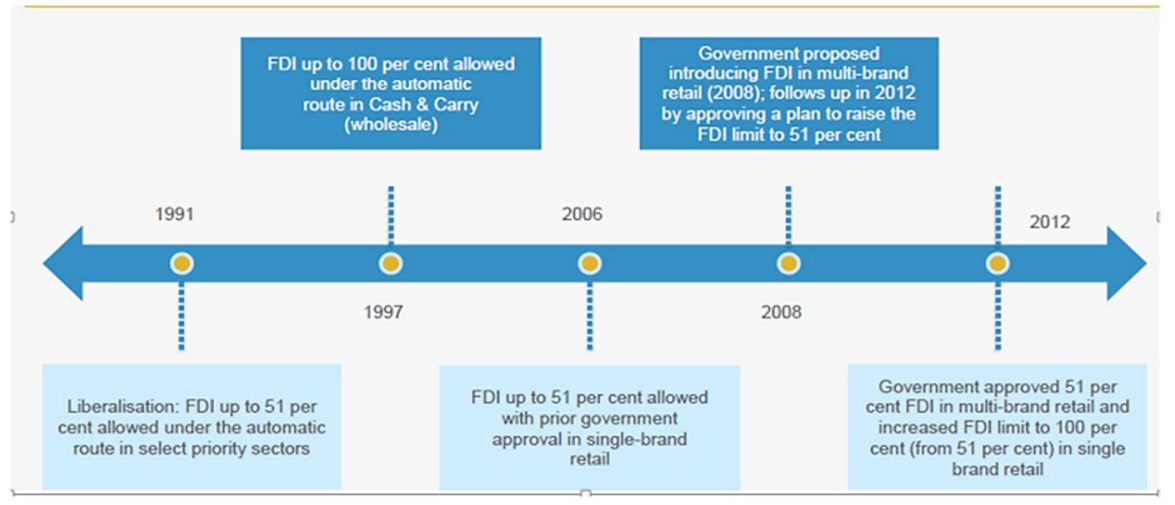

Fig. 1 Changes in FDI policies in retail sector between 1991 and 2012. Source: IBEF Report (2014), www.ibef.org

retail sector; however, comparatively SBRT has liberalised more than the MBRTs which has been rather tightly regulated. ${ }^{1}$

\subsection{Liberalisation of FDI in India}

After Independence from Britain in 1947, Indian economy remained fairly close. In mid-1980s, India faced a severe deficit of balance of payment. The growth in export sector turned negative, and industrial production recorded negative growth. Thus, an attempt to liberalise economy in 1987 was made to overcome balance of payment issue, but that did not succeed. Later in 1990-1991, India's inflation rate was $12 \%$ with current account deficits of $3.1 \%$. During that period, China was an attractive destination for foreign investors; however, India was still facing difficulty. In mid-1991, Indian government foreign exchange reserves were very low, only having enough dollars for two weeks' worth of import. To overcome the problem, India had pledge tonnes of gold to Bank of England and Union Bank of Switzerland. After the disaster of 1991, neoliberal reforms were introduced which was never previously allowed; by opening the economy to initiate privatisation, changes in tax-reforms, deregulation of economic trade practices, allow international trades and investments, control inflation level. The policy of FDI under liberalisation, privatisation and globalisation (LPG) was introduced (Kumar 2008). Initially, very few sectors such as manufacturing, mining were liberalised, but later, more sectors like service, telecommunications, retail were liberalised. The liberalisation is prone to affect various industries, and these effects may vary immensely across industries (Kamath 2007). This research is mainly focusing on the retail sector of India and the impact of liberalisation of FDI policies on retail sector of India.

\footnotetext{
1 Bisaria (2012) defined Single Brand Retail as foreign company can sell their products internationally but only with one brand. Whilst, MBRT allows foreign companies to sell multiple brands under one roof.
} 
In 1997 (Fig. 1), the government of India has approved 100\% FDI in wholesale cash-and-carry market with automatic approval. Later in 2006, FDI of up to $51 \%$ in single-brand retail was allowed by the government subject to prior approval. It was a vital decision and brought huge transformation for the Indian economy and retail sector as well. Between the year 2006 and 2010, 94 proposals had been recorded out of which 57 were accepted and implemented for single-brand retailing. The flow of FDI had increased heavily due to the liberalisation of the economy with FDI of $\$ 1.8$ billion between 2000 and 2010 through retail sector singly (Shah and Parikh 2012). According to Earnest and Young report (2013), FDI is the best tool to enter in the attractive Indian market. It further explains that from last few years India's retail sectors under single-brand retail have emerged as a big opportunity. Adding to it, the IMF's World Economic Outlook report (2015) suggests that between years 2016-2018, Indian GDP growth will be even faster than China. Putting it together with a study by the PWC (2012) which states that, "Indian consumers are among the most confident consumers in the world", it seems highly probable that we will see a surge in consumer spending. Perhaps, annual growth of 15-20 percent has been witnessed in the retail sector. Also, with a high rate of the population falling under 15-59 and being considered as a second largest populated country. A point to consider is that youth and elite consumers had an inclination towards brands and multibrand supermarkets, whereas older generation and non-taxpayers preferred buying from convenience stores, discount stores (Jhamb and Kiran (2012). Economic betterment is considered to be due to the liberalisation of the FDI policies and rigid licensing systems. The retail sector is backbone of Indian economy and one of the fastest growing sectors (IBEF 2016). With that in perspective, this study focuses on the impact of liberalisation policies of FDI in India particularly on retail sector of India. Moreover, it investigates the trends and patterns of FDI flow in the economy and the implication of FDI flow in the organised retail sector. The government allowed $100 \%$ FDI in single-brand retail and 51\% with multi-brand retail with some regulations in 2012. Therefore, following research is based on the impacts of liberalisation of FDI policy in India in retail sector in order to prove the consideration.

The main rationale and purpose of this study are to shed light on the development of the retail sector in India in post-liberalisation era. Furthermore, to understand the growth of retail sector in the very short span of time, as it has been perceived to be related to the post-liberalisation of FDI. Concomitantly, the main research question this study is focusing on is to find what is role FDI has played in the retail sector in the post-liberation era? Although a limited number of studies have highlighted the post-liberalisation in the retail sector, the main contribution this study is intended to make is to gain awareness in the implications of liberalisation on India's retail sector and more specifically in single and multi-brands. There is quite modest work done on the subject of this study, for instance, Kamath (2008) and later Singh et al. (2011) analysed the flow of FDI in India during pre- and post-liberalisation period and showed the trends and patterns of FDI inflow and outflow in India had increased since reform. Similarly, the study by Chopra and Kaur (2014) analyses the flow of FDI inflow and outflow after a post-liberalisation period. However, the present study only shows the trends and patterns of FDI inflow in Indian economy. An important point to emphasise here is that present study highlights mainly on the impacts of the 
liberalisation of FDI policies in India, particularly in retail sector. In order to deduce conclusion, several other aspects need to be considered; hence, we would be looking at the trends and patterns of FDI in Indian Economy, the implications of FDI in retail sector: organised retail over unorganised retail will be explored and also impacts of FDI flow in single-brand retail and multi-brand retail will be analysed. On the whole, the overarching aim and objective of this research are to deduce the impact of FDI had on the retail sector in India post-liberalisation. Further, it also aims to explore the dynamics of growth in the retail sector and challenges faced by the retail sector in the post-liberalisation world.

\section{Literature review}

In following lines, we will highlight the single- and multi-brand retail, organised and unorganised retail sectors of India in the light of previous studies. In 1991, India faced deficits of the balance of payments which paved the way to the liberalisation of FDI policy. Being considered as one of the top attractive destinations for foreign investors, the government has allowed FDI in various sectors of India which includes retail sector. Introduction of FDI policy led to booming of the retail sector in India (Giridhar and Krishna 2013). India's retail sector has witnessed an incredible growth, with the changing demographics, expanding the economy, income dynamics, raising awareness and youth-heavy customer base; India is well on its path to become one of the prospective markets for domestic and global retailers (Jhamb and Kiran 2011). Kumari (2013) examined the effect of FDI on the inflow of equity on trends and patterns of FDI inflow. The study concludes that liberalising FDI policy has benefited Indian economy in a huge manner. FDI introduction has benefited development in various aspects such as infrastructure, expertise and quality of life. However, along with retail sector, Indian government has also liberalised agriculture, insurance and media sector in order to compete with the global economy. According to Renuka et al. (2013), India had introduced FDI with tremendous changes in economic policies heralded liberalisation period and bought structural breakdown in FDI inflows in the economy to maintain fluctuation and unsteadiness during that period.

Despite its benefits, the FDI in the retail sector requires cautious policy measures. On this aspect, Suguna (2016) argued that the FDI in retail would lead to a more comprehensive integration of India into the worldwide market, despite the fact FDI in the energetic Indian retail sector should not just be freely allowed and encouraged. It is imperative for the government to promote the retail sector for the overall economic development and social welfare of the country. Innovative government measures could further mitigate adverse effects on small retailers and traders. Farmers will get another skylight of direct marketing, and they will be better remunerated, but this would require affirmative action and creation of adequate safety nets. In terms of impact on the existing businesses, Manoj (2013) argued that whist the over future outlook of retail sector seems sanguine the competitive pressures may lead to established players withdraw from the market. Concomitantly the established business is endeavouring to innovate to be 
capable of facing competition. Furthermore, in a study by Patibandla (2012) the FDI plays an important role in India's growth dynamics. FDI in the retail sector can expand markets by reducing transaction and transformation costs of business through adoption of advanced supply chain and benefit consumers and suppliers (farmers). This also can result in net gains in employment at the aggregate level. Similarly, Sharma (2013) argued that since the government eased retail policy for the first time, allowing up to 51\% FDI through the single-brand retail route there has been a steady increase in FDI in the retail sector which acts as a major catalyst in the development of a country through upgradation of technology, managerial skills and capabilities in various sectors. Rise in purchasing power, growing consumerism and brand proliferation has led to retail modernisation in India. The growing Indian market has attracted a number of foreign retailers and domestic corporations to invest in this sector. FDI in the retail can expand markets by reducing transaction and transformation costs of business through adoption of advanced supply chain and benefit consumers and suppliers (farmers).

There is also a strand of the literature which cautioned on the externalities of FDI for the Indian retail sector, for instance, Yadav and Jauhari (2012) argued that the debate on FDI in retail sector continues because the retail trade in India is expected to undermine mostly traditional and family business. Though the retail sector is not fully opened for FDI in India, the consequences can be foreseen with reference to the nature of retail in the underdeveloped economy. The government of India is all prepared to open the retail market to place the family business in competition to the domestic and global capital. General macroeconomic variables of employment, poverty, GDP share of trade, per capita income, and marginal population are significantly correlated with the retail sector. The main consequences of FDI in retail trade perceived that it will lead to the widespread closure of small and traditional retail outlets, a sharp decline of the non-formal sector, undermining the livelihood and employment opportunities. Similarly, Mukherjee (2010) analysed that what should be the right policy regime that will help to sustain the growth of retail in India. It was argued that to sustain the growth of this sector, there is an urgent need for regulatory, fiscal, and other reforms. Precisely, the clearances process needs to be streamlined and outdated regulations should be amended. To encourage investment in the supply chain and inflow of technical know-how and skills, the government should allow FDI in multi-brand retail. However, since retail is a sensitive sector, India cannot take an international commitment to liberalisation of retail before streamlining the domestic policy regime.

Three main countries responsible for bringing about fifty percent of FDI inflows were Mauritius, Singapore and USA (Bhaskaran 2012). Manish (2013) examined the economic progress made by Indian retail sector in planning era and issues under globalisation. It also explains socio-economic magnitudes, problems and challenges of the country as well as weakness in FDI planning in India. The retail industry in India comprises 14\% of country's GDP and $8 \%$ of employment and therefore is considered one of the largest retail industries. It is also expected that international brands will invest if FDI in multi-brand is fully flexible. FDI inflow grew twenty times since the government liberalisation over the foreign investment allowances. 


\subsection{Implication of FDI on unorganised retail}

After liberalisation, changes in FDI policies have affected a lot unorganised retailing because giant player has penetrated in the market. As mentioned above, a large number of India's population are engaged in the unorganised sector for their daily survival; changes in FDI policies have immensely affected overall in terms of income, employment, etc. Bhaskaran (2012) explained that retail in India is basically unorganised which cover almost $98 \%$ of the total retail sector. In the study of Mukherjee and Patel (2005), foreign retailers are working with small producers for in-house labelling and delivering new technologies. Thus, it increases the sourcing from India and it brings efficient supply chain management system as well. Bhaskaran (2012) mentioned that late-emerging of India in the modern organised retail market has been due to government's restriction towards foreign investment. On the balance of cost and benefit, Santra and Bagaria (2014) argued that the potential benefits from allowing the large retailer to enter in Indian retail market may outweigh the cost. From the evidence of USA, FDI from organised sector helps to control the increasing trend of inflation mainly wholesale price. It also improves technical knowledge and supply chain system in India specifically for perishable goods like agriculture products. It could create a connection between demand and supply which will improve price single for farmers. With the help of that, it will eradicate the waste of food items and middlemen with an increase in the division of final sales price for farmers and also improves distribution and warehousing channels.

A positive implication due to evaluation in modern retailing is the inflow of FDI in the form of supermarkets in developing and transitioning economies, which emanates higher-quality products, massive product alternatives and lower price offered in the market which is more beneficial to the poor (Ghosal 2014). However, due to increased competition with the foreign retailer, local retailers have faced the vulnerable effects of FDI such as the closure of business and poverty. The local retailer also faces competition in price, product quality and availability, after sale services and safety. Evidence on developing and transition economy showed the negative impact of organised retailer over unorganised retail. The flow of FDI in organised retail resulted declined in traditional retail stores due to giant supermarket investors entered the market. Additionally, the sale of small general stores declined in processed foods and dairy products, whilst the shop producing wet products and fresh product affected less. The shops like outlets faced heavy competition with foreign investors, as they are more capable to buy a huge amount of stock and have large economies of scale (Reardon and Berdegue 2002).

\subsection{Single-brand retailing and multi-brand retailing}

Considering the effects of FDI on India's organised and unorganised retail sectors, there are various aspects to highlight. The term single-brand retail refers to the foreign investors, which would allow investors to trade products in host country under single-brand FDI policy like Reebok, Adidas and Levis. In 2011, union government 
had sanctioned 100\% FDI to single-brand retail which exhibited an increase in goods consumption by the local users. Multi-brand retail focuses on foreign investors willing to sell multiple brands under one roof in compliance to multi-brand FDI policy. This comprises of supermarkets like Walmart, Tesco (Bisaria 2012). Multibrand FDI policy has been restricted by the government with a viewpoint of allowing $51 \%$ of FDI flow, in the city bearing population of more than hundred thousand. However, Jain and Sukhlecha (2012) examined in their study, the requirement of the retail community by inviting FDI in multi-brand retailing (MBR). They concluded that presently it is not quite feasible to increase FDI ceiling greater than $51 \%$ in MBR. The benefit of allowing unrestricted FDI in retail sector evidently outweighs the disadvantages attached to it, and the same can be deduced from the example of successful experiments in other countries like China, where the decision to allow FDI in retail was protested in beginning followed by positive impact on both political and economic grounds.

Various studies include different prospects of FDI in MBR, the current status of FDI in MBR, benefits received by different investors, challenges and criticism in the retail sector in India (Singh 2013). He concluded further that more inclination towards MBR with a change in FDI policy will have a positive impact on local traders in upgrading new technologies and transportation management knowledge from foreign retailers. On the whole, it increases the chances for the Indian economy to get associated with foreign economy along with transformation from highly unorganised to the organised retail sector. According to Gill and Komal (2014), FDI policy in multi-brand sector could have significant reformation in recovering Indian economy, easing supplying pressure, especially in the unorganised sector. The study mainly focused on the perception of the consumers, industrialists, academicians and policymakers in deference to the organised and unorganised retailers. It was concluded that FDI policy liberalisation along with an increase in FDI inflow in retail sector had shown remarkable growth in the economy contributing towards the development of infrastructure, urbanisation of rural areas and personal disposable income of the consumer. Similarly, the role of FDI in multi-brand retail in reference to improving efficiency of food supply food chains in India and its implications on various stakeholders throughout the chain were investigated by Singh (2012a, b). It used the evidence from the experiences of Indian domestic retail and wholesale cash ' $n$ ' carry supermarkets and from developing countries to examine the role of FDI. Study further examined on the mechanism used to leverage the presence of FDI in supermarkets and explore the role of policy and regulation which would help to promote small farmers and traditional retailers in such chains.

Based on above-cited studies, experiences of food supermarkets in several countries reveal that the primary producers have more advantages from such retail linkage rather than small chain producer or farmer which tends to be secluded from the linkage. Liberalisations of the FDI policies have shown the development of the country but on the flip side have affected small-scale local businesses. The traditional retail sector has suffered from the attack of supermarkets in many Asian countries including India's large traditional sector. Introduction of the supermarkets caused inflation in the country which has been due to the introduction of FDI policy in the retail sector. However, Fernandes et al. (2012) analysed FDI in the retail 
sector and its implication on Indian economy and with compare to Singh (2012a, b); they concluded that the FDI liberalisation policy in retail sector bears no threats to small businesses rather it would help to integrate with the global economy. It also states that future economy will be well organised helping to resolve the issues associated with unorganised retail sector providing a quality product at lower price. In long run, it will improve the efficiency of supply chain and other relevant areas and weaken the current negative impact over time. Farmers, small producers and even suppliers would benefit from the introduction of multi-brand in the retail sector. Removing restriction from multi-brand retail will help the agricultural sector to develop and modernised which may generate a higher level of income for farmers. However, large retailers like Walmart and Carrefour showed little interest to participate with farmers in India which constitute about $83 \%$ of the agricultural sector. Therefore, there are only two pathways to convince small-scale farmers to truly realise the advantages of the introduction of FDI in multi-brand retail sector. Firstly, the congregation of small-scale farmers to form producer companies in order to deal with larger retailers and enjoy the perks of high revenue. Secondly, they could quit farming altogether and move towards new areas which are created by FDI in other sectors of the country (Santra and Bagaria 2014).

FDI in MBR permitted by focusing to develop back-end infrastructure, but it is also necessary to develop front-end infrastructure. Bhattacharyya (2012) analysed that economic development, increase in purchasing power, increase in growth of consumerism and brand proliferation have led to modernised retail in India. Per capita income, consumption and consumer awareness increase towards new brands, as the economy liberalises and globalises new brands penetrate the market. FDI offers a win-win situation for both home and host countries. The home countries take the advantage of vast market opened by industrial growth, whilst host countries want to acquire new technological and managerial skills and supplement domestic savings and foreign exchange. However, Jhamb and Kiran (2011) concluded that the strength and opportunities of the organised retail sector are innovative and alternatives in new products, emerging market and young generation. Besides, weakness and threats are high prices of land and shops, an increase in competition level and changes in the consumer demographics.

\section{Research methodology}

We initiate with descriptive statistics and look the trends and patterns of FDI in the retail sector of India and how those trends have affected the organised over the unorganised retail sector. The descriptive strategy has been chosen due to the limitation of available data and empirical options, as inferential statistics is not appropriate considering the face that pre-liberalisation there was not much FDI to analyse. Concomitantly, descriptive statistics such as percentages, annual growth rates and compound annual growth rates (CAGR) are used. The data from 1991 to 2013 on underanalysis variables of interest are collected from the secondary sources based on reports of India Brand Equity Foundation (IBEF), Department of Industrial Policy and Promotion (DIPP) and Bulletins of Reserve Bank of India and local bodies like 
Report of PWC, Report of Earnest and Young, TechnoPak-Retail and international bodies like, United Nation Conference on Trade and Development (UNCTAD), and World Trade Organisation.

\subsection{Analysis and findings}

India is currently the most attractive destination for foreign players to invest and is growing at much faster pace as compared to other countries. ${ }^{2}$ India is known from long time a country with diverse cultures, multilingual, comprehensiveness of people and widespread in geography. Today, world largest democracy leads many other economies of the world in sectors like service, manufacturing, insurance, retail, and so on. With a large number of the population speaking different languages including English, India is emerging ahead in every sector with potential growth. India is attracting international players by providing them plenty of investment opportunity to invest and develop their business in Indian market.

\subsection{Attractive economies for FDI}

It is well clear that China has been world most attractive economies for investors for FDI due to high infrastructural facilities, less congestion in economic structure and convenient business atmosphere. The preferable nations of the world for the FDI are the BRIC nations. BRIC nations include Brazil, Russia, India and China. After liberalisation, the flow of FDI from 1991 to 1999 in India was $0.40 \%$ comparatively to world's FDI. On the other hand, during the same period the share of China was $7.50 \%$, Brazil was $2.60 \%$, and Russia was $0.50 \%$. It further fluctuated to $0.25 \%$ in 2000 and reached $0.76 \%$ in 2005 in India. In 2006, the flow of FDI suddenly reached $1.37 \%$ due to the liberalisation of FDI in the retail sector. Many international supermarkets like Wal-Mart, Carrefour, TESCO have entered the Indian market during this year. The trends of the flow of FDI depicted in Fig. 2 indicate that India has received a considerable amount of FDI every year with slight fluctuation in 2009 and fall down to $1.93 \%$ in 2010 .

The annual growth rate of FDI registered by India in 2013 was $16.54 \%$, whereas China was $2.34 \%$, Russia was $56.68 \%$, and Brazil was negative $1.88 \%$. On the other hand, the compound annual growth rate of FDI registered by India from 1991 to 2013 was 30\%, China was 17\%, Brazil was 19\%, and Russia (from 1992) was $21 \%$. India has registered with the highest growth during this period as compared to other economies, so it can be concluded that India is the most attractive and developing economy for FDI.

\footnotetext{
${ }^{2}$ India ranks 3rd in terms of GDP followed by the USA and China. India ranks 7th largest countries in south Asia and 2nd most populated country in world where $65 \%$ of population is 35 or under and 1.25 billion of population is under 25 years of age (The Guardian UK 2014). Moreover, according to Earnest and Young India is number one FDI destination in the world during the first half of 2015. Available at http://www.ey.com/Publication/vwLUAssets/ey-attractiveness-survey-india-2015/\$FILE/ey-attractive ness-survey-india-2015.pdf.
} 


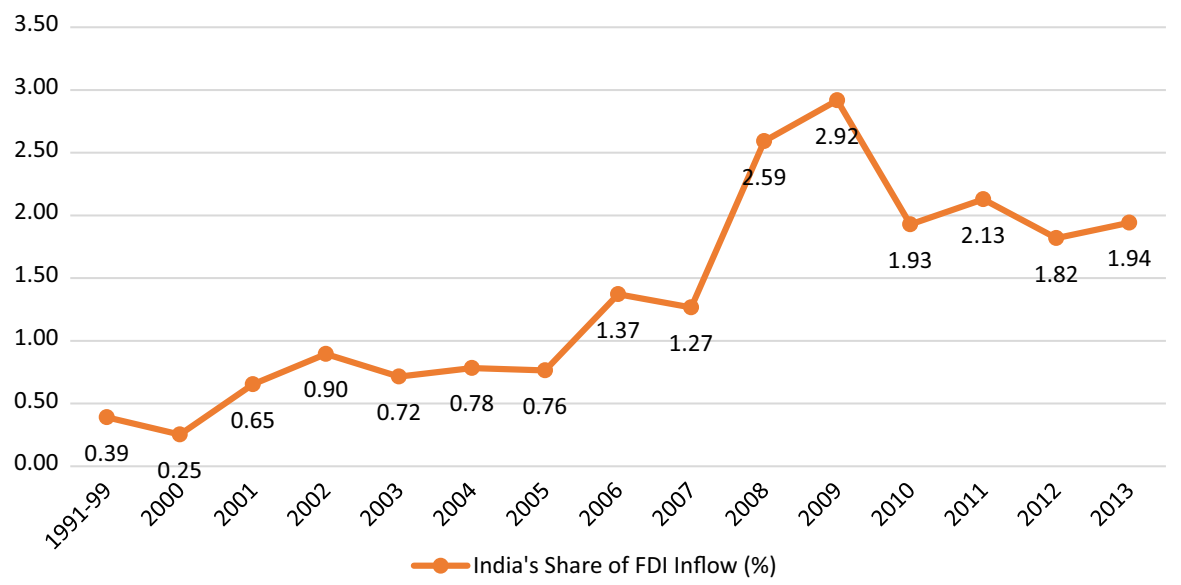

Fig. 2 Share of India in World FDI inflows (\%). Source: Compiled from various issues of FDI statistics WIR Reports, UNCTAD

\subsection{Inflow of FDI in India}

After the decision of liberalising Indian economy in 1991, it has changed the entire picture of the country in comparison with other global economies. India is world's 4th largest and 2nd fastest growing economy in the world currently. The overall aim was to liberalise economic since 1991 have remained same, besides changes in the political parties brought improvements by moving forward from closed economy to market-based economy. The old system of closed economy was full of corruption, strong restrictions, protectionism and slow-moving growth between after independence till 1990. The changes in economic reforms every year registered India on 9th position in terms of industrial output and 3rd in science and technology.

There are several ways in which flow of FDI in India is welcomed, and it is divided into five different heads such as (1) Government Foreign Investment Promotion Board's (FIPB) Approval Route (SIA), (2) Automatic Route by Reserve Bank of India (RBI), (3) Inflow through acquisition of existing shares, (4) RBI's-NRI schemes, and (5) External Borrowings (ADR/GDR). The table and figure show the trend and patterns of FDI from different routes of FDI and the comparison between those routes from the year 1991-2013.

Figure 3 describes the various routes of FDI inflow in India. The Government Approval FIPB - which includes those huge projects in which FDI flows in bulk and requires government approval for implementation, Automatic Route (RBI) and inflow through the acquisition of existing shares represent the small size project FDI inflow which requires no approval from the government since 1995. The flow of FDI from FIPB has shown slow growth compared to automatic route and acquisition of share. The automatic route through RBI has shown upward trends from 1995 with slight fluctuation between 1998 and 1999. The flow of FDI from automatic routes was USD 7.2 billion in 2001 and reached the highest peak of USD 236.51 billion in 2008, but it falls to USD 128.06 billion in 2013. The compound annual growth of 


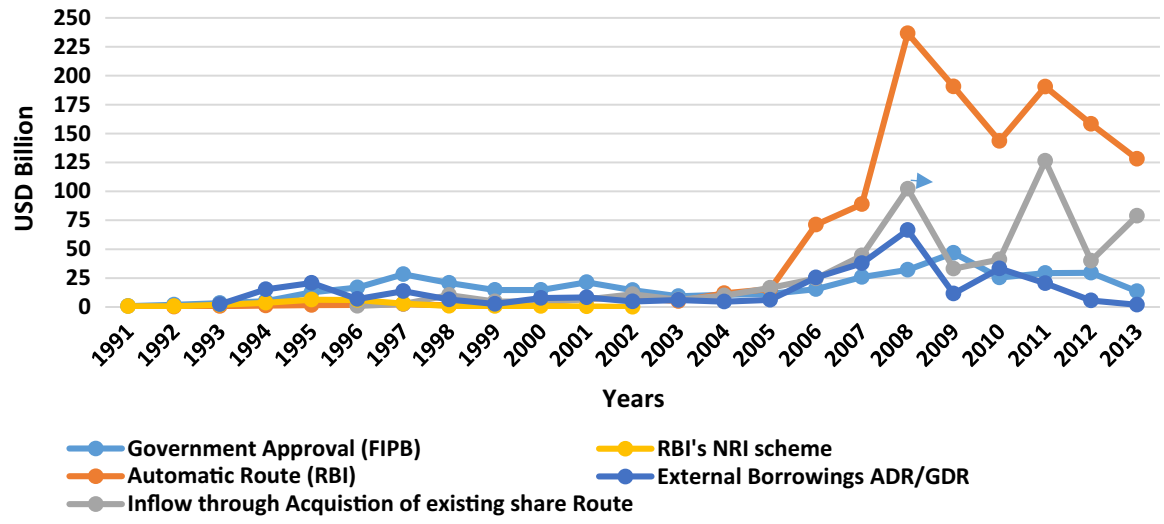

Fig. 3 Flow of FDI in India from different routes (1991-2013). Source: compiled from various issues of SIA newsletters, DIPP, www.dipp.nic.in

FDI from automatic approval between 2001 and 2008 was 54.73\%. FDI flow from the acquisition of the existing share route shows uneven fluctuation every year due to market share prices changes. It was USD 0.88 billion in 1996 and reached USD 10.28 billion in 2002, and USD 102.34 billion in 2008, and USD 126.36 billion in 2011 and again fall down to USD 78.87 billion in 2013. The compound annual growth rate of automatic route flow of FDI from 1991 to 2013 was 34.79\%, and inflow from the existing share route was $28.37 \%$. Thus, from the discussion, we can infer that India has received highest FDI flow of USD 371 billion from a different route because Indian economy has shown an increase in economic growth and sustainable development in the country beside all other nations were suffering crises, which directly or indirectly have increased the confidence of foreign investors. The annual growth in 2008 over 2007 was $122.05 \%$. Flow from external borrowing was USD 2.40 billion, and it increased to USD 66.45 billion in 2008, but it falls down to USD 1.87 billion in 2013. Due to rise in economic growth every year, India has stopped borrowing from external sources for FDI inflow after 2013. Unlike other developing economies such as China, Brazil and Russia, the pace in the flow of FDI in India was competitively low during these years.

\subsection{Country-wise flow of FDI in India}

After the liberalisation of economic reform, India started receiving a flow of FDI all around the globe. During 1991, only 15 countries were investing in India, but it reached 125 countries by 2013 . Thus, it can be presumed that India is most attractive and fastest growing economy compared to other developing economies. Figure 4 shows topmost investors in India from 1991 to 2013 are Mauritius, Singapore, UK, Japan, USA, Netherlands, Cyprus, Germany, France and UAE. Apart from these nations Switzerland, Spain, South Korea and many more are the investors in India, but not the major investor since economic liberalisation. 


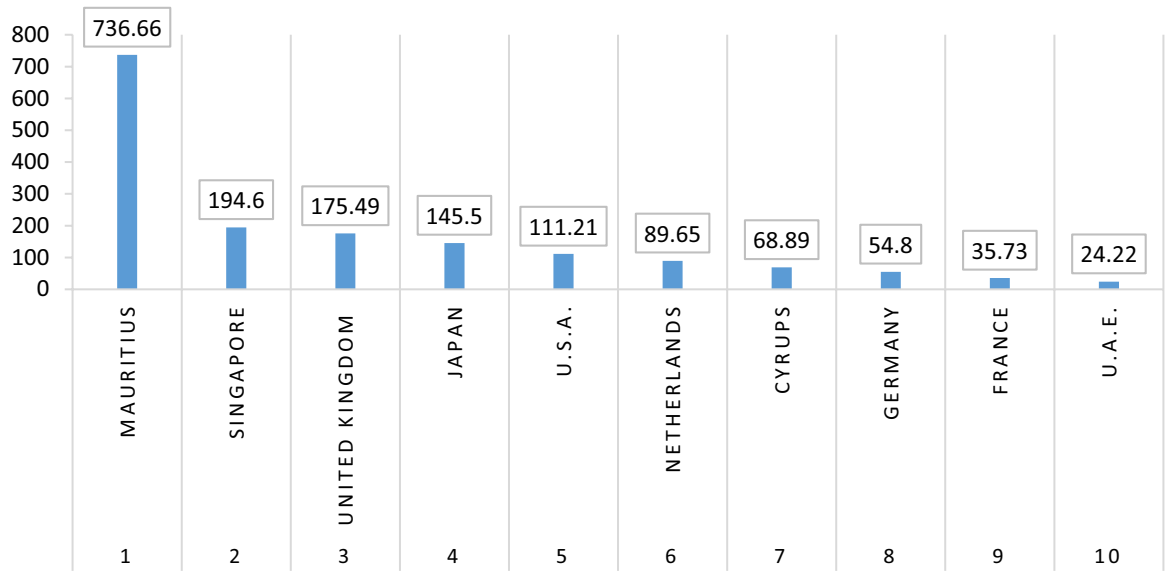

Fig. 4 Top 10 investor/country-wise FDI inflow (USD billion). Source: various Issues of FDI Statistical Report, DIPP, www.dipp.nic.in

There were movements in position between all these years' among countries, but the table shows the situation of 2013. Mauritius is the topmost investor in India after liberalisation till today. The reasons why the Mauritius is on top are the tax advantage due to the agreement between Indian and Mauritius governments came into force on 1 April 1983. ${ }^{3}$ It contributes $38 \%$ of total FDI inflow in India's economy, however, followed by Singapore $10 \%$ which also has a tax agreement with India. Among other countries are the UK 9\% and Japan 8\% and so on. Out of 125 investor countries, these 10 countries contribute more than $85 \%$ of FDI. Total FDI flowed from Mauritius consists USD 736.66 billion from 1991 to 2013. Before few years, the USA was the second investor in India, but now it is Singapore and followed by the UK contributing almost 19\% of total FDI flow which is USD 370.09 billion. Followed by them, Japan, USA and Netherland contribute 19\% of total FDI which consist USD 325.6 billion.

\subsection{Sector-wise flow of FDI in India}

India's economic growth and annual growth of GDP are classified and calculated on the basis of three sectors such as agriculture, industry and service sector (includes retail). During the period before economic reforms, around $80 \%$ of the population of India was engaged in agriculture sector. However, after 1991, India started believing for the development of all three sectors. After the end of licence raj and liberalisation of the economy, India attracts FDI in only a few sectors but compared to 2013 India receives FDI in 63 sectors. Figure 5 shows topmost FDI attractive sectors of India.

\footnotetext{
3 Double Taxation Avoidance Agreement was signed between India and Mauritius and later with Singapore in January 1994.
} 


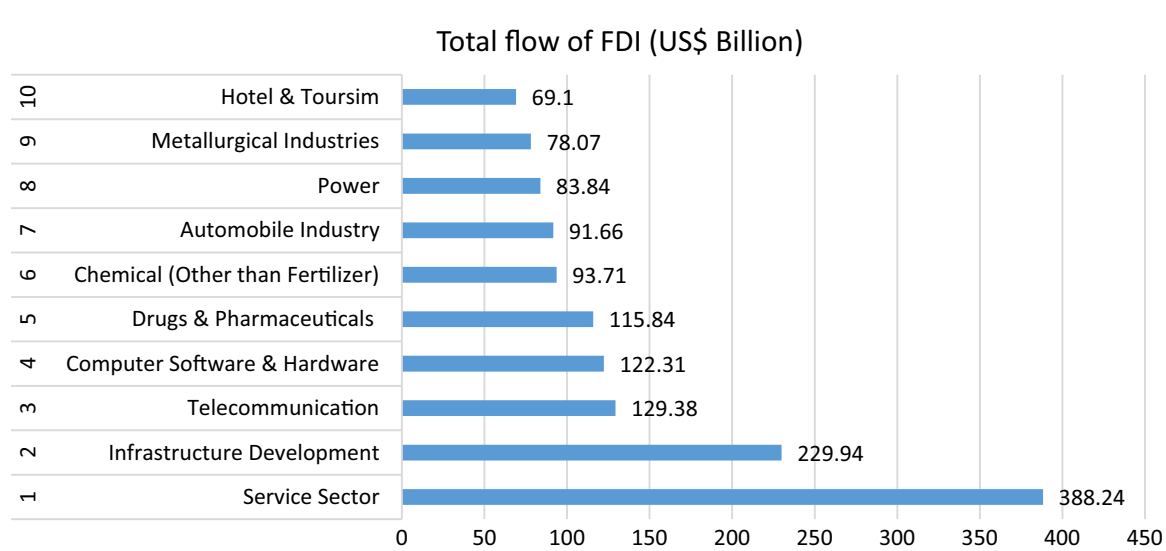

Fig. 5 Top 10 sectors attracting highest FDI in India (2000-2013). Source: from various issues of FDI Statistics reports, DIPP, www.dipp.nic.in

Due to lack of data availability in the sector-wise flow of FDI, analysis from the year 2000-2013 is shown in Fig. 5. Service sector attracts highest FDI in India after the liberalisation of economic reforms. Insurance, banking, retail and others contribute to a share of $19 \%$ of total FDI. The USA was one of the huge investors in service sector, particularly in insurance sector before few years. The other sectors such as infrastructure, telecommunication, computer software and hardware, drug and pharmaceutical, chemical, automobile industry, power, metallurgical industries and hotel and tourism contribute $49 \%$ of total FDI. Before liberalisation, among all three sectors agriculture sector was the huge contributor to GDP, but after liberalisation service sector has undergone significant development contributing around 55\% of total GDP. During 1991, the total GDP of India was $5.29 \%$ out of which $5.19 \%$ of GDP contributed by the service sector, besides that in 2013 the GDP growth of India was $4.47 \%$ out of which share of $6.96 \%$ was contributed by the service sector. India's service sector has the tremendous potentiality to attract more FDI, as the livelihood of a large number of the population depends on this sector. Service sector contributed more than $60 \%$ of total GDP in 2013 and currently as well. Hence, the size of the service sector (which includes retail) reflects its importance in terms of attraction of FDI and for the overall economy.

Retail sector plays an integral part for the development of Indian economy and considered as a major contributor to real GDP growth rate mainly after 2006. The retail sector is expected to grow up to USD 1 trillion by 2020 (IBEF 2016). ${ }^{4}$ Retailing of India has a strong impact over consumer well-being because it provides a wide range of consumer products with good complimentary services, which motivates consumer and provides huge varieties of product to shop. As we know, India's

\footnotetext{
${ }^{4}$ According to The Boston Consulting Group and Retailers Association of India published a report titled, 'Retail 2020: Retrospect, Reinvent, Rewrite', highlighting that India's retail market is expected to nearly double to US $\$ 1$ trillion by 2020 from US\$ 600 billion in 2015. Available at http://www.ibef.org/ industry/retail-india.aspx.
} 


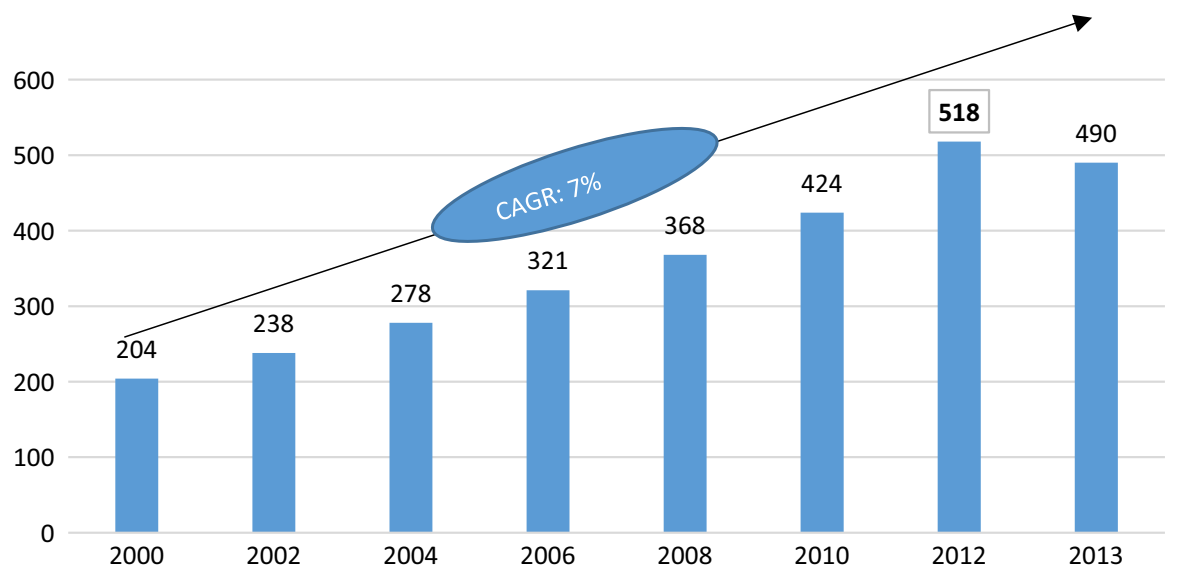

Fig. 6 Total market size (USD Billions) and CAGR. Source: IBEF Report (2014), www.ibef.org

retail was highly unorganised during 1990s; however, after economic reform, it has undergone tremendous change by focusing towards organised retailing. The main aim to motivate organised retail is to attract a foreign player to invest and bring high technology, management skills and expertise, foreign investments and plenty of new products in the market, which overall improve economic growth of country and purchasing power parity of consumer.

\subsection{Organised retailing and unorganised retailing}

The retail sector includes different segments in which FDI is allowed such as food and grocery, consumer durables, speciality products (like footwear, furniture), textile and apparel, music and books and fast food chains. Retailing in India is now changing, though many domestic businesses as well as international entrepreneurs have already entered in retail sectors such as Reliance retail, Titan Industries, Pantaloons, Shopper stop, Aditya Birla Retail, TESCO, Walmart and Carrefour. Organised sector penetration is expected to increase by $7 \%$ in 2012 to $10 \%$ in 2017, with notable $21 \%$ of CAGR in 2017 . It will increase up to $24 \%$ of the total retail sector by the year 2020. This is also born the fact that India has one of the largest retail sector in the world that entails 15 million small shops which sever 209 million households.

\subsection{Market size of Indian retail market}

The employment ratio in the organised retail market is near about a million people in 2013, whereas unorganised retail employs 120 million of the population directly or indirectly. With the benefit of more than a half of India's population fall under the age of 15-49 years increases the demand for food retailing, jewellery, mobile and telecommunication and other segments. With increasing in the number of young 
Table 1 Total retail market share of India (2012). Source: compiled and Calculated from India Retail Report (2013)

\begin{tabular}{lcccc}
\hline Retail categories & $\begin{array}{l}\text { Total market } \\
\text { (USD billion) }\end{array}$ & $\begin{array}{l}\text { Modern retail mar- } \\
\text { ket (USD billion) }\end{array}$ & $\begin{array}{l}\text { Share \% of total } \\
\text { retail market }\end{array}$ & $\begin{array}{l}\text { Share \% } \\
\text { of modern } \\
\text { market }\end{array}$ \\
\hline Food and grocery & 311.3 & 4.62 & 1 & 11 \\
Clothing and apparels & 40 & 13.5 & 34 & 33 \\
Mobile and telecom & 29.6 & 4.4 & 15 & 11 \\
Food services & 24.3 & 2.8 & 12 & 7 \\
Jewellery & 23.3 & 2.4 & 10 & 6 \\
Consumer electronics & 17.3 & 3.5 & 20 & 8 \\
Pharmacy & 15.4 & 0.8 & 5 & 2 \\
Home and interiors & 14.8 & 2.2 & 15 & 5 \\
Entertainment and gaming & 13.2 & 1.3 & 13 & 3 \\
Beauty and personal care & 9 & 1.2 & 7 & 3 \\
Eyewear & 6 & 0.43 & 18 & 1 \\
Leisure & 5.3 & 0.98 & 38 & 2 \\
Footwear & 4.3 & 1.65 & 12 & 6 \\
Fashion accessories & 2 & 0.24 & 52 & 1 \\
Time wear & 1.6 & 0.83 & 25 & 2 \\
Fitness & 0.6 & 41 & & 1 \\
Total & 518 & & & 5 \\
\hline & & 0.15 & 25 & 2 \\
\hline
\end{tabular}

population, retail sector demand and people purchasing power are also increasing in India.

Figure 6 shows the market of modern retail sector between 2000 and 2013. In the year 2000, the size of the market was USD 204 billion which reached USD 238 billion and USD 278 billion in 2002 and 2004, respectively. In 2006, retail market size was increased to USD 321 billion due to liberalisation in the retail sector. The compound annual growth rate between 2000 and 2006 was $6.69 \%$. However, after a change in policy the growth of retail market size has shown significant growth in following years. In the year 2012, the retail market size has increased to USD 518 billion and achieved annual growth rate $22.17 \%$ in a year. It further falls down to USD 490 billion in 2013 due to economic crises and high inflation rate. From 2000 to 2013 , the compound annual growth of market size was $7 \%$.

The analysis in Table 1 shows the total market size of the different segments in the year 2012. Food and grocery contribute to major share USD 311.3 billion of the total retail market in 2012. Comparatively, modern retail market contributes only USD 4.62 billion, i.e. $1 \%$ share of the total retail market (Fig. 7). This is due to still a large amount of population engaged unorganised retail in food and grocery sector and people still believe buying food products as well as household products from small shops but not from supermarkets. Clothing and apparel contribute a share of USD 40 billion to the market during 2012. Comparatively, the size of the modern retail market was USD 13.5 billion, which share $34 \%$ of total 


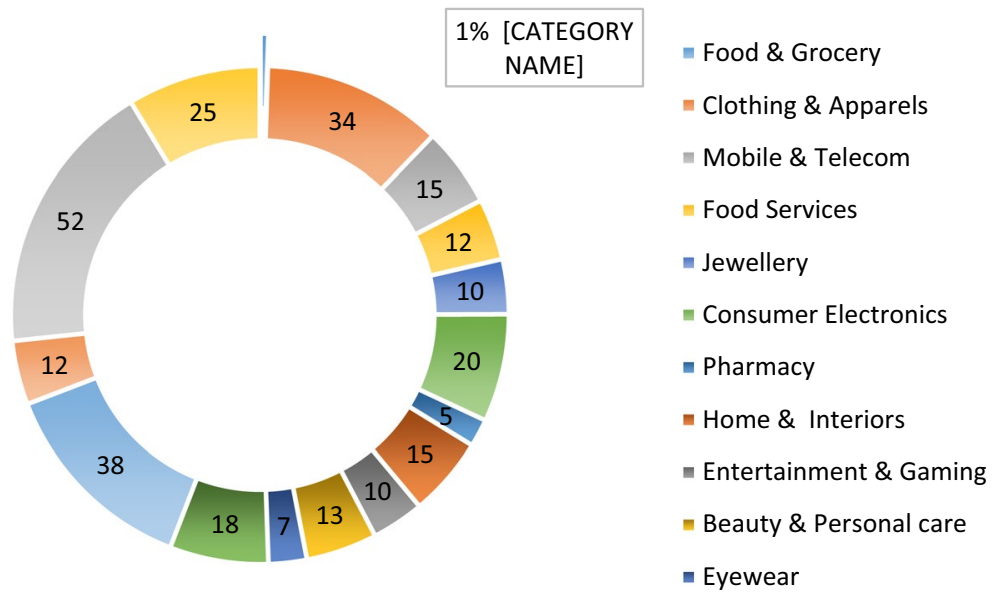

Fig. 7 Total retail market share of India (2012). Source: compiled and calculated from India retail report (2013)

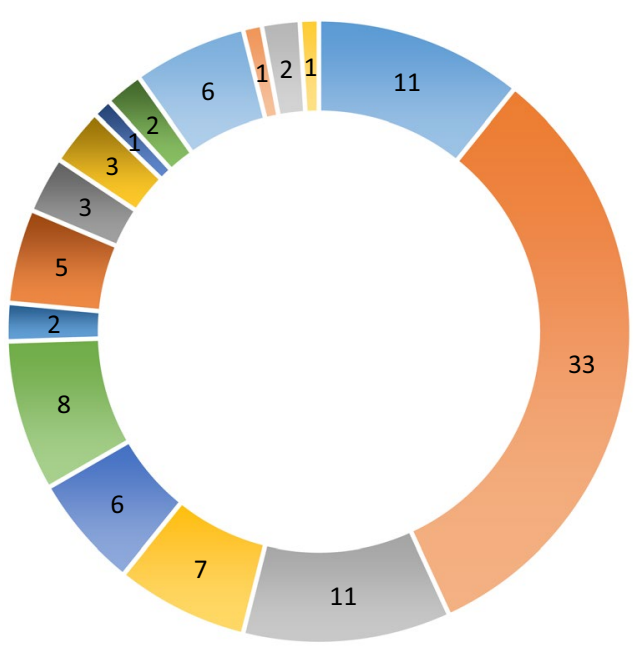

$$
\begin{aligned}
& \text { = Food \& Grocery } \\
& \text { = Clothing \& Apparels } \\
& \text { = Mobile \& Telecom } \\
& \text { = Food Services } \\
& \text { = Jewellery } \\
& \text { = Consumer Electronics } \\
& \text { - Pharmacy } \\
& \text { - Home \& Interiors } \\
& \text { - Entertainment \& Gaming } \\
& \text { - Beauty \& Personal care } \\
& \text { - Eyewear } \\
& \text { - Leisure } \\
& \text { - Footwear }
\end{aligned}
$$

Fig. 8 Share percentage of segment of total modern retail market. Source: compiled and calculated from India retail report (2013)

market size. This segment attracted a high number of foreign investors which includes Italy, Japan, USA, Europe, Turkey and China.

Similarly, mobile telecom, food services, jewellery and consumer electronics contribute $15,12,10$ and $20 \%$ of the total market, respectively. In the year 2012 , India's total retail market size was USD 518 billion of which only USD 41 billion was modern retail market. It can be deduced that India's retail market is still way far from high modernisation compared to USA (85\%), as only $8 \%$ of the total 
Table 2 Number of retail formats and share of total space. Source: compiled from India Retail Report (2013)

\begin{tabular}{|c|c|c|c|c|c|c|}
\hline \multirow[t]{2}{*}{ Formats } & \multicolumn{2}{|l|}{2006} & \multicolumn{2}{|l|}{2011} & \multicolumn{2}{|l|}{2016} \\
\hline & No. of stores & $\begin{array}{l}\text { Total share } \\
(\%) \text { space }\end{array}$ & No. of stores & $\begin{array}{l}\text { Total share } \\
(\%) \text { space }\end{array}$ & No. of stores & $\begin{array}{l}\text { Total share } \\
\text { (\%) space }\end{array}$ \\
\hline Convenience stores & 100 & 0 & 400 & 0.3 & 2000 & 1 \\
\hline Hypermarkets & 40 & 10 & 300 & 17 & 1000 & 25 \\
\hline Discount Stores & 500 & 2 & 1500 & 2 & 4000 & 2 \\
\hline Speciality stores & 10,000 & 75 & 30,000 & 50 & 50,000 & 37 \\
\hline Department stores & 50 & 7 & 600 & 20 & 1400 & 21 \\
\hline Cash-and-carry & 2 & 1 & 30 & 2 & 200 & 7 \\
\hline
\end{tabular}

retail market is modernised. Figure 8 depicts the share percentage of each segment out of the total modern retail market.

Figure 8 shows the percentage of share contributed by each segment in the modern retail market. The segment of clothing and apparel shows $33 \%$ of share in the total modern market during 2012. Following to food and grocery and mobile and telecom, both contribute to $11 \%$ of the total modern market in 2012. However, other segments of retail sector are still struggling to get double figures of a percentage because some investors are fighting to develop their customer base in those segments.

\subsection{Retail formats}

The retail formats have developed in different phases; the first phase was started in late 1990s with the concept to develop departmental store, which proved to be very successful and popular. The second phase was broadly coming up with three different types of formats in 2005 such as hypermarkets, supermarkets and convenience stores. The main aim to this phase was to test the market of all these formats which create awareness among consumers. The third phase brought major implementation in retail formats during 2008 and 2010, as many giant international players have entered into the market with the launch of various malls and cash-and-carry markets. Current phase after 2010 is aiming more to attract international players to invest in existing formats and by bringing new innovative technology and greater shopping environment. There are different retail formats and investments by domestic business giants in those formats such as supermarkets/hypermarkets, department stores, speciality chains, discount stores, wholesale cash-and-carry, convenience store.

Table 2 shows 40 hypermarkets were sharing $10 \%$ of space throughout India in 2006, which increased to 300 hypermarkets by 2011 sharing $17 \%$ of total space in the market. Discount stores are the small stores which require less space with 500 stores in 2006 share $2 \%$ space, which increased to 1500 in 2011. The major market of retail formats was shared by speciality stores with 30,000 stores in 2011 which share $50 \%$ of space; it was 10,000 stores with a share of $75 \%$ market space. There were only 50 departmental stores in 2006 with a share of $7 \%$ market which increased 
Table 3 Flow of FDI in singlebrand retail 2007-2013 (USD billion). Source: compiled from various issues of SIA newsletters, DIPP, www.dipp. nic.in

\begin{tabular}{lcl}
\hline Years & Flow of FDI (USD billion) & $\begin{array}{l}\text { Share \% of } \\
\text { total flow of } \\
\text { FDI }\end{array}$ \\
\hline 2007 & 0.02 & 0.07 \\
2008 & 2.2 & 8.00 \\
2009 & 15.43 & 56.00 \\
2010 & 3.14 & 11.41 \\
2011 & 2.8 & 10.17 \\
2012 & 3.3 & 12.00 \\
2013 & 0.63 & 2.30 \\
Total & 27.52 & \\
\hline
\end{tabular}

to 600 stores in 2011 with $20 \%$ of sharing total space. The importance of hypermarket and supermarkets is increasing in the retail market as more and more stores are launched in short period of time. It can be further deduced from Table 2, hypermarkets and supermarkets share space will increase to $25 \%$ and $21 \%$ of total space in 2016 , whereas speciality stores share space will decrease to $37 \%$ of total space.

\subsection{FDI flow in single-brand retail and multi-brand retail}

Retail sector attracts FDI in two ways such as single-brand retail and multi-brand retail. In 2006, India has removed restriction by allowing $51 \%$ of FDI in singlebrand retailing. The term single brand emanates "a foreign investor can sell the only single-brand product under one roof in Indian market", whilst in "multi-brand retail multiple brands can be sold under one roof". The changes in policies in single-brand retail have attracted large amount from foreign investors in the market. To encourage multi-brand retail, many proposals were submitted and in 2008, the government accepted proposal into consideration but that too failed. In 2012, the government of India has approved FDI in multi-brand retailing up to $51 \%$ but with some considerations. However, with the changes in policy, FDI in single-brand retailing increased to $100 \%$ with automatic approval route from RBI. The retail sector of India has born to start modernising since 2006 and registered 16\% of GAGR in 2013. It is expected to reach $19 \%$ of CAGR with the end of the year 2015 .

Table 3 shows the total FDI flow in the retail sector in under the category of single-brand retail between 2007 and 2013. The government of India had liberalised retail sector in 2006 by allowing foreign investment in single-brand retail. In 2006, more than 50 international investors have registered to invest in Indian market. The FDI started to flow in 2007 with a very minimal amount of USD 0.02 billion and reached USD 2.2 billion in 2008. In the year 2009, Indian retail has received a remarkable flow of FDI about USD 15.43 billion with a growth rate of more than $600 \%$ and CAGR of $817 \%$. Then, it fell down to USD 3.4 billion in 2010, because of heavy competition and restriction of single-brand retail of $51 \%$ of FDI allowance.

In 2012 with the proposed changes in FDI policy, retail sectors too liberalised further in single-brand retail and multi-brand retail. However, the flow of FDI has 
reduced in 2013 due to the weak political background which failed to attract investors in the Indian market. A major company TESCO supermarket of UK has entered first in India for multi-brand retail in 2013 with a USD 110 million initial investments in the retail market of India. As a further step towards liberalisation, India has allowed up to $100 \%$ FDI in the multi-brand processed food retailing in the budget for the fiscal year 2016-17 (Union Budget 2016). However, the complete liberalisation of FDI in multiple brand retails is yet to come, and as described by the Wall Street Journal (2016) report, multi-brand retailing has been a sticky issue in India as critics argue the introduction of foreign supermarkets to the sector would erode business at more than 12 million traditional retail vendors.

\section{Discussion}

India is welcoming FDI as it has the huge potentiality to adjust the large amount of FDI for their infrastructural development, employment generation, skill and expertise generation, to maintain balance of payment, and to achieve high economic growth. Among all sectors of India, service sector receives the highest flow of FDI since 1991. This is due to the reason that a large proportion of the population is engaged with the services sector. For instance, activities related to business, finance and non- finance and retail services. Hence, by inviting more foreign player has increased the flows of investment in the service sector, the foreign plays enjoy the wide market area, cheap labour, and low cost of training. In this regard, the subject study has made a contribution to the debate on the FDI and liberalisation of the Indian economy by focusing the retail sector.

Since the beginning of liberalisation in 1991, organised retailing growth depicted drastic improvement. But giving more importance to organised retailing, a large proportion of the population engaged in unorganised retailing has gone through negative effects such as unemployment, closure of business, less footfall, increase in poverty and many others. On one side, the flow of FDI in organised retail has improved India's GDP and Global Retail Development Index (GRDI) rank, but on the other side, it has affected the day to day survival of many people. According to GRDI 2012, India ranks 5th in attracting economy of the world followed by Brazil, Chile, China and Uruguay. The aim of the Indian government has been to encourage organised retailing, thereby attracting more international investors to contribute towards Indian economy. Many people who were engaged in unorganised retailing have moved to organised retailing. This happened due to an increase in knowledge about the modernisation of retail market and benefits attached to modern retailing. Thus, it can be said that giving more importance to modern retailing has short-term negative effects but it also has stronger positive effects in the longer term.

Foreign direct investment allowance in single-brand retailing was the significant step of the Indian government to attract more foreign investors in the Indian market. As an implication of this policy, the retail sector of India has shown tremendous growth after removal of restriction in single-brand retail in 2006. It was the step towards modernising retail market of India from where a huge amount of money contributes Indian economy. The popularity of single-brand retailing has shown 
increasing growth since 2006; thus, government has allowed FDI 100\% in 2012 with the removal of half restriction in multi-brand retail. Reflecting on the importance of this policy decision, Pinakiranjan Mishra (2015), the Partner and National (Retail) for Ernest and Young has quoted that: "Multi-Brand Retail is the most important step for the retail sector that will not only give a philip to the players but also the associated stakeholders like suppliers, supply chain providers, etc. besides creating a lot of jobs. More importantly this will be seen as a strong message to the international community that reforms are finally backed on track. We see the positive impact of this well beyond the retail sector". This was the most important initiative by the Indian government towards the development of retail market by allowing more FDI in multi-brand retail. However, the government is yet on fully convinced to raise the restrictions applied to the multi-brand retail.

\section{Conclusion}

Discussion based on findings leads us to conclude that encouragement and facilitation of international investors in India have created ample opportunities. Improving retailing sector was the vital requirement, as the retail sector was the contributor of the total income of the nation. However, due to highly unorganised market of India during pre-liberalisation of the economy, income generating from retailing was not greatly contributing to the economy. Therefore, FDI in retail has a greater role to play in future improvement in retail sector from highly unorganised to modernised retail. Concomitantly, based upon the descriptive statistical analysis and discussion, it can be concluded that India has come across huge diversification in every sector in terms of growth and infrastructure development since liberalisation began. However, but still there is a long way to go. Government has liberalised many sectors including retail but as retail is the backbone of India, it still requires more restrictions to be removed and allow people of India to fully experience modernised retailing. In terms of policy implication, further liberalisation may have some negative effects on the traditional players which could not compete with global competitiveness pressure, however, that shall not impede on the ability to implement the policy of liberalisation. Instead, the measure should be taken to facilitate the structural change associated with further liberalisation. These may include the development of human capital and labour force to facilitate the smooth transition and reducing the unemployment associated with the structural change in the industry. Nonetheless, this may also be an aspect to consider in the fiscal management and allocation of resources to those sectors of economy which are negatively influenced by the liberalisation.

Although the research has reached its aims and objectives of deducing the impact of liberalisation of FDI policy in the retail sector of India, there are some unavoidable limitations in terms of the collection of data; it was difficult to gather primary data. There are also some methodological limitations and use of the descriptive approach which was due to the availability of data. Therefore, for further research, contingent on the availability of data, parametric statistical techniques such as 
regression analysis can be used, perhaps a counterfactual situation which might be possible through simulation models yet beyond the scope of this study.

\section{Compliance with ethical standards}

Conflict of interest The authors declare that they have no conflict of interest.

Open Access This article is distributed under the terms of the Creative Commons Attribution 4.0 International License (http://creativecommons.org/licenses/by/4.0/), which permits unrestricted use, distribution, and reproduction in any medium, provided you give appropriate credit to the original author(s) and the source, provide a link to the Creative Commons license, and indicate if changes were made.

\section{References}

Bhaskaran K (2012) The FDI permit for multi brand retail trading in India—green signal or red signal. Bus Intell J 5(1):176-186

Bhattacharyya R (2012) The opportunities and challenges of FDI in retail in India. IOSR J Hum Soc Sci 5(5):99-109

Bisaria DG (2012) Foreign direct investment in retail in India. Int J Eng Manag Res 2(1):31-36

Chopra S, Kaur S (2014) Analysis of FDI inflows and outflows in India. J Adv Manag Sci 2(4):326-332

Department of Industrial Promotion and Policy (DIPP) (2000-2013) SIA Newsletters, Government Annual Reports 2000-2013, New Delhi, India. http://dipp.nic.in/English/Publications/SIA_NewsL etter/SIA_NewsLetter.aspx. Accessed 1 May 2018

Department of Industrial Promotion and Policy (DIPP) (2000-2013) FDI Statistics, Government Annual Reports 2000-2013, New Delhi, India. http://dipp.nic.in/English/Publications/FDI_Statistics/FDI_ Statistics.aspx. Accessed 1 May 2018

Ernst and Young India (2013) Indian single brand retail—poised for growth. http://www.ey.com/publi cation/vwluassets/ey-indian-single-brand-retail-poised-for-growth/\$file/ey-indian-single-brand-retai 1-poised-for-growth.pdf. Accessed 1 May 2018

Fernandes LM, Ruksanabanu A, Simon S (2012) FDI in multi-brand retail: issues and implications on Indian economy. Pac Bus Rev Int 5(5):19-28

Ghosal M (2014) Impact of foreign direct investment on unorganised retail sector of India-a research report. SIJ Trans Ind Financ Bus Manag (IFBM) 2(1):1-8

Gill HS, Komal (2014) Impact of multi brand foreign direct investment in retail sector in India. Pac Bus Rev Int 6(12):7-16

Giridhar KV, Krishna MM (2013) Foreign direct investment in India: challenges and opportunities in multi-brand retail sector. Int J Retail Rural Bus Perspect 2(1):272-276

India Brand Equity Foundation (2014) Indian retail industry analysis. http://www.ibef.org/pages/36797. Accessed 10 Mar 2016

India Brand Equity Foundation (IBEF) (2016) India Brand Equity Foundation (IBEF) annual report. https ://www.ibef.org/annual-report.aspx. Accessed 1 May 2018

India Retail Report (2013) New Delhi, India. http://www.indiaretailing.com/imagesonlinebookstore/ booksdetail.aspx? bookid $=8 \&$ type $=2$. Accessed 1 May 2018

International Monetary Fund (2015) World Economic Outlook (WEO) Uneven growth: short- and longterm factors. [http://www.imf.org/external/pubs/ft/weo/2015/01/. Accessed 10 Mar 2016

Jain M, Suklecha ML (2012) FDI in multi-brand retail: Is it the need of the hour? Zenith Int J Multidiscip Res 2(6):108-131

Jhamb D, Kiran R (2011) Organized retail in India-drivers facilitator and SWOT analysis. Asian J Manag Res 2(1):264-273

Jhamb D, Kiran R (2012) Emerging trends of organized retailing in India: a shared vision of consumers and retailers perspective. Middle-East J Sci Res 11(4):481-490

Kamath B (2007) Trade liberalization its impact on the import dependence of the consumer goods versus capital goods industry. Mumbai School of Economics and Public Policy, University of Mumbai 
Kamath B (2008) Impact of foreign direct investment in India. J Int Bus 3(4):16-38

Kumar A (2008) Paradoxes of paradigm shift: Indian engagement with liberalization and globalization. Futures 40(8):762-766

Kumari N (2013) A study of FDI in India. J Econ Sustain Dev 4(3):25-40

Manish K (2013) FDI in Indian retail sector today: the benefits will come tomorrow. Int J 7(6):109

Manoj PK (2013) Problems and prospects of retailing industry in India: a macro perspective. Int J Res Commer Manag 3(5):1-9

Mishra P (2015) Announcement on FDI in multi-brand retail. http://www.ey.com/IN/en/Newsroom/Ernst -Young-quotes-Announcement-on-FDI-in-multi-brand-retail. Accessed 1 May 2018

Mukherjee A (2010) Fuelling India's retail boom: What should be the right policy? Adv Int Mark 9(21):57-74

Mukherjee A, Patel N (2005) FDI in retail sector India: report by ICRIER and Ministry of Consumer Affairs, Food and Public Distribution, Govt. of India: 2005. Academic Foundation, New Delhi

Patibandla M (2012) Foreign direct investment in India's retail sector: some issues. Indian Institute of Management Bangalore, Working Paper No: 366

PWC (2012) The Indian kaleidoscope emerging trends in retail, FICCI. https://www.pwc.in/assets/pdfs/ industries/retail-and-consumer/retail-report-300812.pdf. Accessed 1 May 2018

Reardon T, Berdegué JA (2002) The rapid rise of supermarkets in Latin America: challenges and opportunities for development. Dev Policy Rev 20(4):371-388

Renuka R, Ganesan M, Durgamani M (2013) Impact of FDI in Indian economy with special reference to retail sector in India. Glob J Res Anal 2(1):22-24

Reserve Bank of India (RBI) (2000-2013) RBI Bulletins, Government Publications, New Delhi, India. www.rbi.org.in/scripts/BS_ViewBulletin.aspx?Id=14582. Accessed 1 May 2018

Santra S, Bagaria N (2014) Foreign direct investment in retail market in India: some issues and challenges. J Econ 2(1):1-10

Shah V, Parikh A (2012) Trends, changing composition and impact of foreign direct investment in India. Int J Econ Res (IJER) 3(4):134-144

Sharma MK (2013) FDI in Indian retail: challenges. CLEAR Int J Res Commer Manag 4(10):90-92

Singh S (2012a) Role of FDI in multi-brand retail trade in India and its implications. Rev Mark Integr 4(3):283-308

Singh T (2012b) Does public capital crowd-out or crowd-in private capital in India? J Econ Policy Reform 15(2):109-133

Singh V (2013) FDI in multi-brand retail sector-a study regarding Indian context. Asia Pac J Mark Manag Rev 2(7):121-131

Singh J, Jha SR, Singh Y (2011) Impact of liberalization on foreign direct investment: an empirical analysis of Indian economy in post-reform period. IUP J Public Finance 9(3):23-33

Suguna P (2016) Opinion of the retailers on the new FDI policy: an analysis. J Manag Thought Pract $8(1): 75-85$

Union Budget (2016) Union Budget of India. http://indiabudget.nic.in/budget.asp. Accessed 10 Mar 2016

United Nation Conference on Trade and Development (UNCTAD), World Investment Report (WIR) (1991-2013) FDI statistics, Switzerland. http://unctadstat.unctad.org/wds/ReportFolders/reportFold ers.aspx?sRF_ActivePath=P,15912\&sRF_Expanded=,P,15912. Accessed 1 May 2018

Wall Street Journal (2016) India mulls lifting FDI limit for multibrand food retail. http://www.wsj.com/ articles/india-mulls-lifting-fdi-limit-for-multibrand-retail-1451993284. Accessed 10 Mar 2016

Yadav HS, Jauhari S (2012) Foreign direct investment and retail trade in India (the consequences under globalization). Skyline Bus J 7(1):34 